\title{
MODERNIZATION OF NEW IRRIGATED LANDS IN A SCENARIO OF INCREASING WATER SCARCITY: FROM LARGE RESERVOIRS TO SMALL PONDS
}

\author{
W. JLASSI ${ }^{1}$, E. NADAL-ROMERO ${ }^{2}$, J.M. GARCÍA-RUIZ ${ }^{3 *}$ \\ ${ }^{1}$ National Agronomic Institute of Tunisia (INAT), Tunis, Tunisia. \\ ${ }^{2}$ Dpto de Geografía y Ordenación del Territorio, Facultad de Filosofía y Letras, Instituto de Investigación \\ en Ciencias Ambientales de Aragón (IUCA), Universidad de Zaragoza, Spain. \\ ${ }^{3}$ Instituto Pirenaico de Ecología, Consejo Superior de Investigaciones \\ Científicas (IPE-CSIC), Zaragoza, Spain.
}

\begin{abstract}
Large rainfed, dryland areas were transformed into irrigated land in northeast Spain, where rivers from the Pyrenees Range ensure the availability of abundant water resources. The transformation of the Riegos del Alto Aragón area (RAA), mainly during the second half of the 20th century, was subject to major problems during the 1960s and 1970s, including monoculture of poorly productive winter cereals, water wastage, and soil degradation. Since the 1990s the RAA has been affected by modernization involving: (i) a change in the mode of irrigation, from gravity to sprinkler systems; (ii) the concentration of plots to enlarge the size of irrigated fields; and (iii) the introduction of more productive and highly water-consuming crops (corn, lucerne, vegetables). These changes coincided with enlargement of the irrigated area, increasing water demand at a time of increasing water scarcity because of restriction on the construction of new large reservoirs and declining water resources, because of climate and land use changes. Addressing this major problem has required new strategies, specifically the construction of small reservoirs and water ponds within the irrigated area. The ponds increase water reserves and facilitate sprinkling irrigation by adding pressure to the system. However, this has involved a huge rise in electricity consumption, which has increased the cost of production.
\end{abstract}

Modernización de una nueva área de regadio en un escenario de creciente escasez de agua: de grandes embalses a pequeñas balsas

RESUMEN. Extensas áreas de secano fueron transformadas en regadío en el nordeste de España, donde los ríos procedentes de los Pirineos aseguran la disponibilidad de abundantes recursos hídricos. La transformación de Riegos del Alto Aragón (RAA) durante la segunda mitad del siglo XX ha estado sujeta a grandes problemas durante las décadas de 1960 y 1970, incluyendo el monocultivo de cereales de invierno escasamente productivos, despilfarro de agua y degradación del suelo. Desde la década de 1990 RAA se han visto afectados por un proceso de modernización que implica: (i) un cambio en la técnica de riego, pa- 
sando de riego por gravedad a aspersión; (ii) la concentración parcelaria para aumentar el tamaño de los campos regados; y (iii) la introducción de cultivos más productivos y muy consumidores de agua (maíz, alfalfa, cultivos hortícolas). Estos cambios han coincidido con la ampliación del área de riego, un aumento de la demanda de agua en un momento de creciente escasez debido a la dificultad para que se acepte la construcción de nuevos grandes embalses, y un descenso de los recursos hídricos debido al Cambio Global (cambio climático y de usos del suelo). La solución a este gran problema ha necesitado de nuevas estrategias, incluyendo la construcción de pequeños embalses y balsas dentro de la zona de regadio. Las balsas aumentan las reservas de agua y facilitan el riego por aspersión al añadir presión al sistema. Sin embargo, esto ha implicado un gran aumento del consumo de energía, que ha incrementado los costes de producción.

Key words: irrigated land, irrigation modernization, reservoirs, water ponds, Monegros, Spain.

Palabras clave: regadío, modernización del regadío, embalses, balsas, Monegros, España.

Received 16 December 2015 Accepted 3 January 2016

* Corresponding author: J.M. García-Ruiz, Instituto Pirenaico de Ecología, Consejo Superior de Investigaciones Científicas (IPE-CSIC), Campus de Aula Dei, P.O. Box 13.034, 50080-Zaragoza, Spain. E-mail address: humberto@ipe.csic.es

\section{Introduction}

Irrigation has been and remains a key factor in the development of agriculture and civilization in the Mediterranean region (Higueras, 1969; Frutos, 1993; Lasanta, 2009). The control of water enabled resilience to climatic variability, and therefore to the seasonal and interannual irregularity of water resources. This led to greater societal complexity because it provided food surpluses and security against climatic fluctuations. Mediterranean rainfed agriculture has traditionally been based on cereals (varieties of wheat, barley, oats and rye), vineyards, and olive and almond orchards (i.e. crops harvested prior to the coldest and driest period of the year, or plants with long roots and the ability to take water from deep soil or bedrock layers). This is because the Mediterranean region is subject to exceptionally hot and very dry summers (from June to late September) that enhance evapotranspiration and create water stress problems for natural vegetation and cultivated plants (Wainwright and Thornes, 2004). The occurrence of long drought periods, a characteristic typical of the Mediterranean climate (Vicente-Serrano and Cuadrat-Prats, 2007), has encouraged the expansion of irrigated lands in suitable small areas, such as the lower terraces of small rivers having continuous stream flow.

Small-scale irrigated areas developed on the Iberian Peninsula among indigenous peoples prior to the Roman conquest (Higueras, 1969; Albiac et al., 2007). Romans and Arabs consolidated the irrigation areas (Puy, 2014) by building small reservoirs 
and irrigation ditches, and established increasingly complex rules governing water use (Laliena, 2008). The occurrence of greater technical and financial resources following the end of the 18th century resulted in a change of scale in use of water from the Ebro River, with completion of the large Imperial Canal of Aragón Project (which had precedents in the 16th century) (Fernández Marco, 1961), followed by construction of the Canal of Castilla (Duero River basin) and the Canal of Lodosa and the Canal of Aragón and Catalonia (Ebro River basin).

From the end of the 19th century, politicians and farmers concluded that improvements in Spanish agriculture and the livelihoods of farmers would only be possible under semi-arid climatic conditions through the development of large irrigated areas on relatively flat lands situated in the vicinity of major rivers having substantial discharges, using large and complex infrastructures such as reservoirs and canals. This was the origin of the new irrigated lands in Tierra de Campos (Duero River basin), Bardenas and Monegros in the central Ebro Depression, the so-called Plan Badajoz (Guadiana River basin), and the enlargement of the irrigated areas in southeast Spain throughout the Tagus-Segura water transfer, together with other minor plans for expanding the irrigated areas (e.g. in the Tagus basin: García-Ruiz et al., 2010). In some cases, the transformation of rainfed cultivated lands into irrigated lands was achieved by using groundwater resources, resulting in severe environmental problems and a decline in water resources, as was the case of the Upper Guadiana River (Sanjuan, 2013). This was a successful process until recent decades: the irrigated area in Spain increased by $80 \%$ during the period 1961-1999 (Strosser et al., 1999), reaching a total of almost $3.5 \mathrm{M}$ ha in 2011. Irrigation is particularly important in the Ebro Valley (783,948 ha in 2006), above all in the Community of Aragón (399,045 ha).

By 1915 the Spanish Government approved the development of the Riegos del Alto Aragón Project (RAA) in the middle of the Ebro Depression, which is an area having very poor rainfed crops, extreme interannual rainfall variability, and general water scarcity even for domestic uses. The project was based on the use of water from two of the main tributaries of the Ebro River, the Gállego and Cinca rivers, and the construction of a complex network of large reservoirs and long canals able to supply water to 300,000 ha. This area of irrigation was initially foreseen as necessary to increase agricultural productivity, to retain population in the rural areas and to serve as a basis for the development of agro-industries (Castelló, 1989; García-Ruiz et al., 2003; Bouzaida and Frutos, 2006a). The project developed very slowly until the second half of the 20th century (Pinilla, 2008), with different changes that reduced the irrigated area to 170,000 ha and finally to approximately 125,000 ha, one of the largest irrigated areas in Europe. The project is still far from complete, but faces two main problems: (i) restriction on increasing the availability of water resources; and (ii) the need to modernize the entire irrigated area to improve the efficiency of the irrigation systems (Faci et al., 2000; Playán and Mateos, 2006; Frutos et al., 2008; Lecina et al., 2010), which paradoxically will lead to an increase of water consumption per hectare.

The main purpose of this paper is to analyse the changes undergone over several decades by a large, modern irrigation plan (the RAA), the challenges it faces and the 
(provisional) solutions adopted to enable expansion of the irrigated area under conditions of increasing water scarcity.

\section{The study area}

The RAA is located in the middle of the Ebro Depression (northeast Spain) between the Gállego (to the west) and Cinca (to the east) rivers, which are two of the main Pyrenean tributaries of the Ebro River. The northern limit corresponds to the Cinca Canal and the southern limit to the Monegros Canal (Fig. 1). The RAA belongs to the Community of Aragón, mainly to the Province of Huesca and secondarily to the Province of Zaragoza, and is located between $41^{\circ} 21^{\prime}$ to $42^{\circ} 09^{\prime} \mathrm{N}$ and $0^{\circ} 18^{\prime}$ to $0^{\circ} 43^{\prime} \mathrm{W}$. The irrigated lands are located between 200 and $500 \mathrm{~m}$ a.s.l. Most of this area has been known as Monegros, which is one of the driest parts of the Iberian Peninsula, and hence one of the driest in Europe. Nevertheless, some municipalities in the northernmost part of the RAA are located beyond the limits of Monegros.

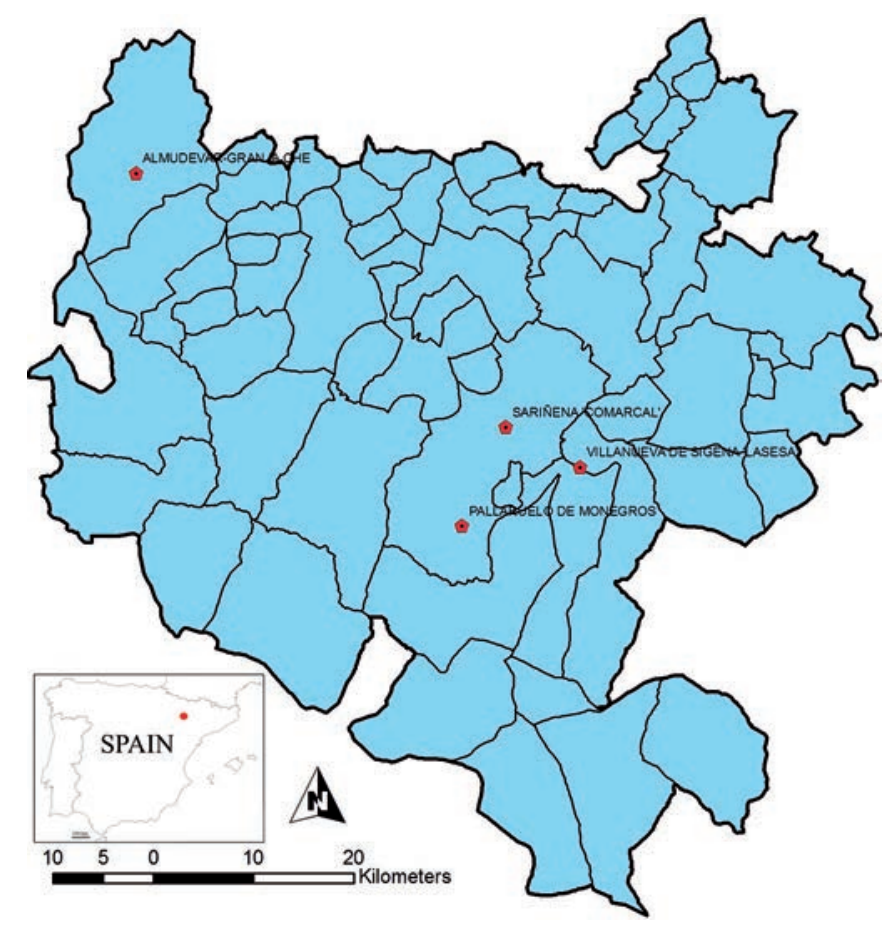

Figure 1. The study area, showing the location of the weather stations.

The Ebro Depression is one of the largest morphostructural units of the Iberian Peninsula, forming a topographically depressed area between the Pyrenees, the Iberian Range and the Catalan Coastal Range. From the edge to the centre it is composed of: conglomerates, sandstone, sandstone with mudstone, mudstone, marl and, in the central area, salt, gypsum and limestone. These materials were not later affected by tectonic 
deformation, and except for some local movements of the gypsum, they remain oriented horizontally. Structural relief, pediments, flat-bottomed valleys and fluvial terraces are the most characteristic landforms.

The climate is dry Mediterranean, somewhat continentalized, and mainly characterized by scarce and highly variable annual precipitation of approximately $400 \mathrm{~mm}$ per year (Almudévar, $442 \mathrm{~mm}$; Pallaruelo de Monegros, $348 \mathrm{~mm}$ ). The monthly precipitation shows two main rainy periods, one in spring (May, followed by April) and the other in autumn, and two dry periods, in summer and winter (Fig. 2). Figure 3 shows the evolution of annual precipitation between 1940 and 2007, and indicates high variability particularly since 1990, when approximately $200 \mathrm{~mm}$ was recorded in some years. The four gauging stations show a slight, but not statistically significant, negative trend in recent decades. The average annual temperature is $13-14.5^{\circ} \mathrm{C}$, with averages of $22^{\circ} \mathrm{C}$ and $23^{\circ} \mathrm{C}$ in July and August, respectively, and approximately $0^{\circ} \mathrm{C}$ in January and February. Other climatic features having a major influence on crop productivity are the occurrence of frequent frosts in December-March, westerly winds (almost 30\% of the days each year, particularly in February, March and April), fogs (20-25 days per year) and summer rainstorms. Potential evapotranspiration exceeds $800 \mathrm{~mm}$ per year (Ibarra and de la Riva, 2006), and consequently the study area is affected by major water deficits, particularly from June to October.
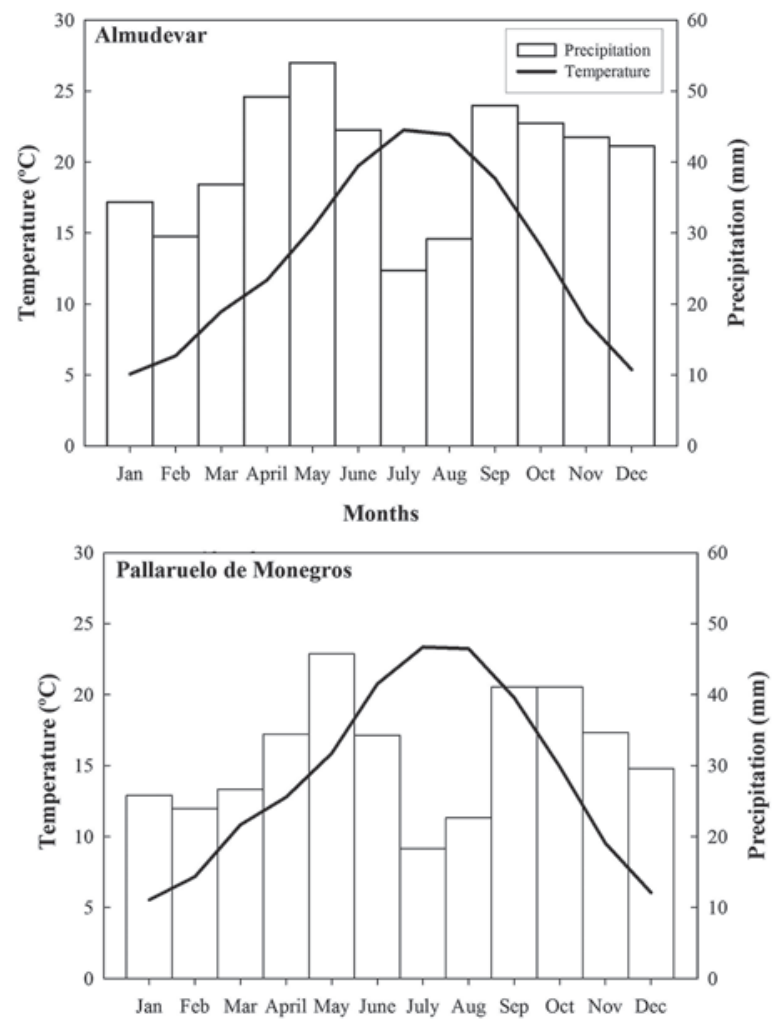

Figure 2. Average monthly precipitation and temperature at two weather stations in the study area. 


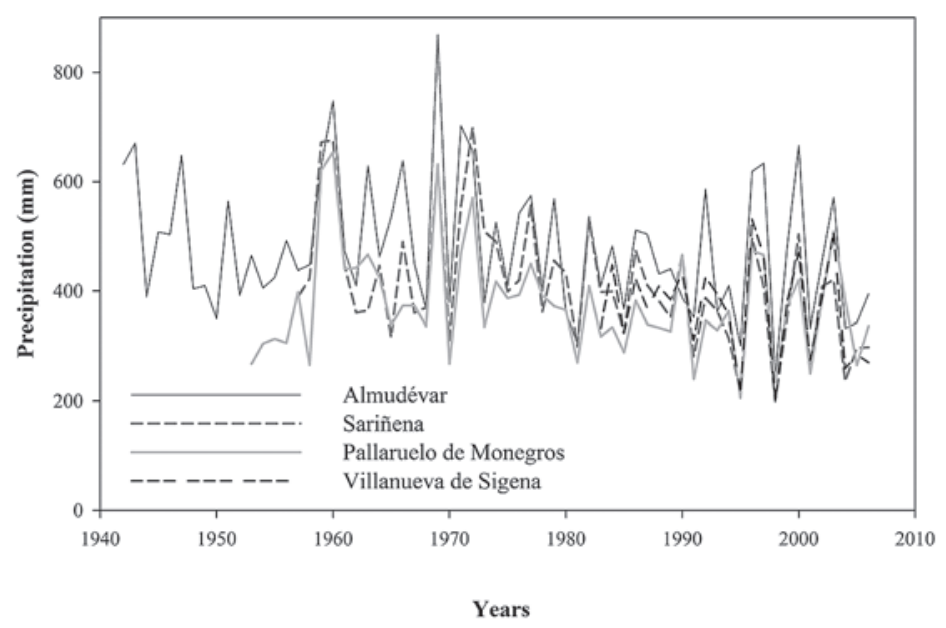

Figure 3. Evolution of the annual precipitation at four weather stations in the study area.

The soils generally correspond to semi-arid typologies because of the scarce annual precipitation, high summer temperatures and bedrock characteristics. In general, they are low in nutrients and organic matter content, have poor permeability, are frequently salty, have a basic pH (Navas and Machín, 1997), and have a marked tendency to develop crusts because of raindrop impacts and splash, and evaporation (Ibarra-Benlloch and Pinilla-Navarro, 1999; Lasanta et al., 2000). Calcaric cambisols (in the oldest pediments and fluvial terraces), calcisols, fluvisols and gypsisols occur extensively throughout the study area.

The Gállego and Cinca rivers rise in the central part of the Pyrenees, in an area having peaks of $>3000 \mathrm{~m}$ a.s.l., where the average annual precipitation is approximately $2000 \mathrm{~mm}$. The average discharge of these rivers in the Ebro Depression is $29 \mathrm{~m}^{3} \mathrm{~s}^{-1}\left(930.5 \mathrm{hm}^{3}\right)$ and $50.2 \mathrm{~m}^{3} \mathrm{~s}^{-1}\left(1581.3 \mathrm{hm}^{3}\right)$, respectively. The average monthly discharge is maximal in late spring because snowmelt and frontal rainfall; relatively low discharges occur in winter, because of the retention of snow in the headwaters. Nevertheless, the importance of snowmelt to spring discharges has decreased slightly in recent decades, because of declining snow accumulation (López-Moreno, 2005), and the maximum discharge occurs earlier (López-Moreno and García-Ruiz, 2004). Other minor rivers originate in the Pre-Pyrenees (the Flumen, Guatizalema, Alcanadre and Vero rivers), but these have low and irregular discharges. It is noteworthy that they receive surplus water (return flows) from the irrigated area, and consequently their volumes increase from April to October as they cross the semi-arid environment of the Ebro Depression (García-Ruiz et al., 2001).

The original vegetation of the study area has been markedly disturbed by the expansion of rainfed and irrigated fields, overgrazing and fires (Pedrocchi-Renault, 
1998). The plants in the non-cultivated areas are adapted to local extreme conditions, including high insolation, low levels of precipitation, strong winds, soil degradation and a long history of human activity (Pueyo, 2013). On north-facing slopes, forests of evergreen oaks (Quercus ilex rotundifolia) and Mediterranean pines (Pinus halepensis) can be found. In areas affected by strong winds and thermal inversions in winter, the only tree species is Juniperus thurifera, which form open forests and also occurs as isolated trees on the borders of cultivated fields. The degradation of such forests has resulted in various shrub formations that are dominated by Quercus coccifera, Rhamnus lycioides, J. oxycedrus, Pistacia lentiscus and Rosmarinus officinalis. In the most degraded areas the landscape is dominated by Artemisia herba-alba, Salsola vermiculata and Lygeum spartum. It is probable that some areas in Monegros have maintained their steppe-like aspect for thousands of years (Pedrocchi-Renault, 1998; Ibarra and de la Riva, 2006).

\section{Materials and Methods}

The methods used included:

(i) Interviews with various stakeholders in the study area, including those from the RAA Administration Office, people with extensive knowledge on the functioning of the irrigation system (engineers working in the RAA, scientists), and farmers;

(ii) Obtaining information from the RAA Administration Office, particularly data concerning ponds and small reservoirs, and the management of water resources under contrasting climatic conditions (dry and wet years);

(iii) Obtaining information from the Ebro River Administration Office on river regimes, average discharges in the irrigated canals and reservoir management;

(iv) Field work consisting of the study of various characteristics of the RAA, particularly comparison of the landscape between the modernized and non modernized sectors of the irrigated lands; and

(v) Mapping of ponds in the RAA area, using the visor IBERPIX of the Spanish Geographic Institute (Instituto Geográfico Nacional, IGN).

\section{Results}

\subsection{The organization of the Riegos del Alto Aragón Project}

Figure 4 shows a general diagram of the organization of the RAA Project, including the main reservoirs and canals. As noted above, the project is based on the Gállego and Cinca rivers, which store and provide all of the water resources used within the irrigation system comprising 125,899 ha. 


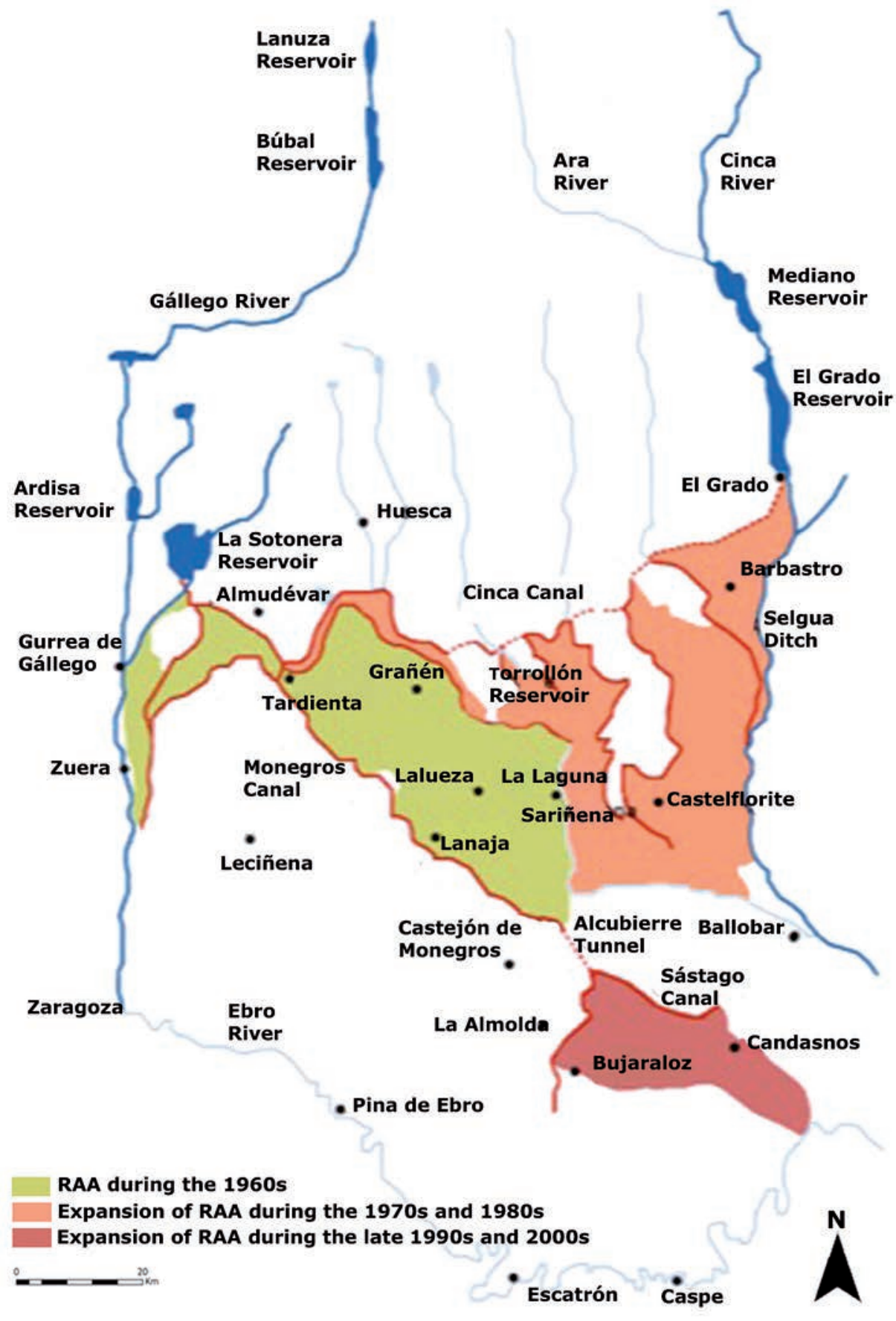

Figure 4. Organization of the RAA Project. The three main steps in expansion of the RAA. 
The first step in the project was the construction of a small dam on the Gállego River at Ardisa, to enable diversion of water to the Sotonera reservoir and from there to the RAA system. The Ardisa dam was completed in 1934.

The Sotonera reservoir is close to the Gállego River. Although its construction commenced during the 1920 s it was only completed in 1963 with a greater capacity $\left(189 \mathrm{hm}^{3}\right)$ than that foreseen in the original project. The Sotonera reservoir is not in the Gállego River proper, but forms a large dammed mudstone depression to which water from the Gállego River arrives through the Gállego Canal, which has a capacity of $90 \mathrm{~m}^{3} \mathrm{~s}^{-1}$. The Sotonera reservoir is a key part of the RAA system, because it is the origin of the Monegros Canal (capacity: $90 \mathrm{~m}^{3} \mathrm{~s}^{-1}$ at the foot of the reservoir: length: $133 \mathrm{~km}$ ), which supplies water to a large part of the RAA system.

Upstream of the Ardisa dam the Gállego River is also dammed to form the Lanuza, Búbal and La Peña reservoirs. The Lanuza reservoir (capacity $25 \mathrm{hm}^{3}$ ) was constructed in 1978 and is located close to the headwater, and the Búbal reservoir was constructed in 1971 (capacity of $64 \mathrm{hm}^{3}$ ). The La Peña reservoir, which is located in a small marly depression in the Pre-Pyrenees, has a capacity of $25 \mathrm{hm}^{3}$. It was constructed in 1913 as an initiative of the farmers of the lower Gállego River and is not integrated in the overall management of the RAA system. It is noteworthy that a new reservoir (the Biscarrués reservoir; planned capacity $34 \mathrm{hm}^{3}$ ) is now proposed in the Gállego River proper immediately upstream of the Ardisa dam. The initial proposal was for a larger capacity $\left(180 \mathrm{hm}^{3}\right)$, but this was strongly opposed by the local population and environmental groups. Besides, the storage of water in the Biscarrués reservoir will only be possible when the discharge in the Gállego River exceeds $90 \mathrm{~m}^{3} \mathrm{~s}^{-1}$ (average discharge $29.5 \mathrm{~m}^{3} \mathrm{~s}^{-1}$ at Santa Eulalia de Gállego). Another proposal for a reservoir at Almudévar (off the Gállego River, as for the Sotonera reservoir) is still at a very initial stage, with a capacity for $169.7 \mathrm{hm}^{3}$ (flooded area: $1152 \mathrm{ha}$ ). It faces the problem of the need to pump water from the Gállego Canal, which will involve high electricity costs.

In the Cinca River there are two main reservoirs (the Mediano and El Grado reservoirs) dedicated to water supply to the RAA and to hydropower production. The Mediano reservoir has a capacity of $438 \mathrm{hm}^{3}$ and was completed in 1971. The El Grado reservoir (capacity $399 \mathrm{hm}^{3}$ ) is located downstream of the Mediano reservoir, but only $240 \mathrm{hm}^{3}$ can be used for irrigation purposes, because the Cinca Canal does not start at the base of the El Grado dam, but at mid height.

The Cinca Canal has a capacity of $72 \mathrm{~m}^{3} \mathrm{~s}^{-1}$ and a length of $88 \mathrm{~km}$. It is orientated westward and meets the Monegros Canal at the so-called Embrance of Tardienta (Abrazo de Tardienta), where the waters from the Gállego and Cinca rivers join and increase the volume of water available in the Monegros Canal, which has enabled expansion of the irrigated land toward the southeast of the study area. Several minor canals are derived from the Cinca and Monegros canals: the Violada irrigation ditch (capacity $8 \mathrm{~m}^{3} \mathrm{~s}^{-1}$; length $37 \mathrm{~km})$; the Flumen Canal $\left(17 \mathrm{~m}^{3} \mathrm{~s}^{-1} ; 60 \mathrm{~km}\right)$; the Sástago Canal $\left(32 \mathrm{~m}^{3} \mathrm{~s}^{-1}\right.$; $22 \mathrm{~km})$ from the Monegros Canal; and the Selgua $\left(8 \mathrm{~m}^{3} \mathrm{~s}^{-1} ; 35 \mathrm{~km}\right)$, Terreu $\left(17 \mathrm{~m}^{3} \mathrm{~s}^{-1}\right.$; $49 \mathrm{~km})$ and Pertusa $\left(11 \mathrm{~m}^{3} \mathrm{~s}^{-1} ; 37 \mathrm{~km}\right)$ canals from the Cinca Canal. A total of 57,700 ha is directly irrigated from the Cinca Canal, approximately 60,000 ha are irrigated from 
the Monegros Canal upstream of the Alcubierre Tunnel, and approximately 8000 ha are irrigated downstream of the Alcubierre Tunnel (the so-called Monegros II Project). The tunnel traverses the Alcubierre Range and enables irrigation of part of the southern area around the municipality of Bujaraloz.

Construction of the Montearagón reservoir $\left(52 \mathrm{hm}^{3}\right)$ in the Flumen River has recently been completed. It is designed to supply water to the city of Huesca, and to irrigate 5000 ha in the vicinity of the city. Spare water from this reservoir can be diverted towards the RAA, and its storage can be integrated into the RAA system.

This above highlights the complexity of the RAA system, which includes various reservoirs (with a total capacity of $943.9 \mathrm{hm}^{3}$ ), canals, irrigation ditches, hydropower stations, thousands of kilometres of rural tracks, and has involved the construction of ten new villages in the initial stages of the development of the project (Bouzaida and Frutos, 2006b). This complexity has been increasing in recent decades, as the irrigated area has enlarged and the entire system has undergone a process of modernization.

\subsection{Expansion and modernization of the $R A A$}

The expansion of RAA has been a slow process of development of irrigated lands. As noted above, the project was approved by the Spanish Government in 1915, but it is not yet complete. Political and economic problems caused substantial delays during the initial stages of the project, particularly the construction of the Ardisa dam (in 1934) and the key Sotonera and Mediano reservoirs, even though the initial proposal was considerably reduced in size. The original project was designed to irrigate approximately 300,000 ha, but the extent of the irrigated area is presently 125,899 ha. The maximum extent foreseen for the future is limited by the availability of more water resources from new reservoirs.

Figure 4 shows the three main steps in the expansion of the RAA:

(i) The oldest sector, located in the western part of the RAA, was made possible by construction of the Ardisa dam and the Sotonera reservoir, and the Monegros and Flumen canals;

(ii) Construction of the Mediano and El Grado reservoirs and the Cinca Canal (and the secondary Selgua, Terreu and Pertusa canals) enabled a second large development in the eastern sector of the RAA.

(iii) The third step involved transformation of rainfed fields to irrigated land in the extremely dry area in the vicinity of Bujaraloz, on the southern side of the Alcubierre Range, and was made possible by construction of the Alcubierre tunnel and the Tardienta Embracement (1982).

Since the 1990s the RAA has been subject to a process of modernization. In terms of irrigated areas, this has involved the application of more efficient irrigation systems, which enable crop productivity to be optimized (Albiac et al., 2007). This process was initiated for several reasons. Firstly, the farmers of the RAA were accused by conservationist groups of wasting water. Secondly, several scientific studies and reports 
concluded that the use of water was inefficient, given the extensive cropping systems prevailing in the area (Lecina et al., 2010). In fact, the farmers substituted rainfed cereals by irrigated cereals; although productivity increased markedly, it was far less than expected (Bouzaida, 2004). In addition, the irrigation system involved inundation of the fields with water derived from irrigation ditches (irrigation by gravity, a major cause of piping erosion in irrigated fields: García-Ruiz et al., 1997; García-Ruiz, 2011). As a consequence, the drainage canals received much return water flows, in some cases by water loaded with nutrients (particularly nitrates) and salts. This increased the salt content in the main fluvial network (Lasanta et al., 2001; Isidoro et al., 2006; Isidoro and Grattan, 2011; Causapé et al., 2012), as has occurred in other irrigated lands in the Ebro Depression (Causapé et al., 2006). Thus, too much water was used, and nutrient and salt contamination occurred.

This situation was ecologically and economically unsustainable. In an attempt to improve the ecological sustainability of farming, to increase the efficiency of use of the available (and increasingly limited) water resources, and to raise the productivity of the land, since the 1980s there has been a radical change in the use of water and the types of crops grown (Playán and Mateos, 2006). Thus, the modernization process included changes to: (i) the irrigation system; (ii) the size and other characteristics of cultivated fields; and (iii) the crops used.

The change in the irrigation system involved progressive expansion of the use of sprinkling irrigation. This has theoretically reduced the quantity of water needed each time the land is irrigated because it enables more precise control of the quantity of water used. This change has had other positive consequences, including: (i) a reduction in the compaction of the land; (ii) the potential to irrigate undulated, non-terraced fields; (iii) the ability to automate the irrigation system; (iv) an increase of $25-50 \%$ in crop yields and an improvement of the working conditions of farmers (Lecina et al., 2009); and, most importantly, (v) a reduction in the nutrient and salt outputs (Albiac et al., 2007; Lecina et al., 2009). With respect to the latter, $31 \mathrm{~kg} \mathrm{ha}^{-1}$ of nitrates is released from the modernized sector compared with $68 \mathrm{~kg} \mathrm{ha}^{-1}$ from gravity-irrigated areas (Tedeschi et al., 2001; Cavero et al., 2003; Isidoro et al., 2006). In addition, the drainage canals have reduced the return flows (or drainage outflows) derived from the modernized areas (Lecina et al., 2010). However, a negative consequence is that watering by sprinklers is ineffective in strong winds, in some cases necessitating that irrigation be postponed (Playán et al., 2005). This is a serious problem in the Ebro Depression, where northwestsoutheast winds are very common, even during summer.

The introduction of sprinklers was accompanied by an increase in the size of plots through plot concentration in order to improve the efficiency of mechanized labour (ploughing, seeding, harvesting) and the irrigation procedures. Plot concentration has also involved the removal of steps between plots and bench-terraced fields, causing locally the occurrence of rills and sheet wash erosion. Bench-terraced fields are still indispensable when watering by gravity, i.e. in the oldest irrigated sectors, behaving as traps of water and sediment. In the municipalities affected by modernization, watering by sprinklers and plot concentration developed together. However, sprinkling irrigation 
creates a new and significant problem in that the use of sprinklers necessitates that the water be distributed under pressure.

Figure 5 shows the percentage distribution of the area under sprinkler irrigation within each municipality of the RAA, and highlights that there is a high proportion in the eastern sector, where the switch from rainfed to irrigated agriculture has been more recent. In the southeastern part of the RAA, which was modernized during the 2000s, sprinkling irrigation occurs in approximately $100 \%$ of the area. In the western sector, watering by gravity still dominates and advancement towards modernization remains very slow. In total, the modernization process has affected 67,570 ha. It is noteworthy that sprinkling irrigation is most common on properties of middle (20-100 ha) and largest (>100 ha) size.
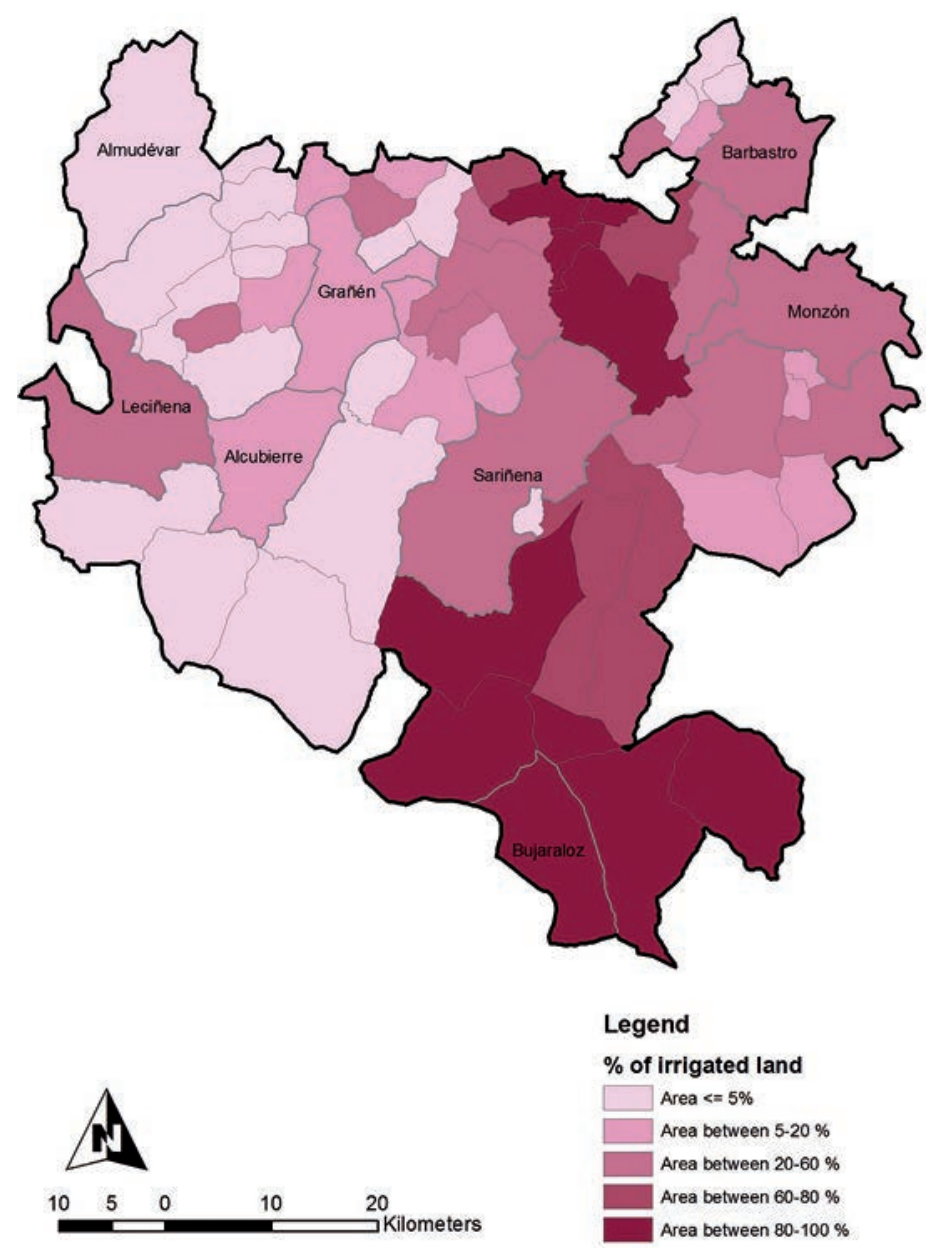

Figure 5. Percentage of sprinkler irrigation in relation to the total irrigated area in the municipalities of the RAA. 
An immediate consequence of modernization was a change in the crops under cultivation. Winter cereals have largely been replaced by corn and lucerne, and by rice in the valley bottoms and on relatively salty soils on non-transformed benchterraced fields. Other crops have also been introduced including endives, garlic, onion, cabbage and, to a lesser extent, fruit tree orchards. Vineyards in the northeastern part of the RAA have also been modernized with the introduction of drip irrigation systems. In a parallel way livestock production has undergone a remarkable increase, particularly pigs $(940,000$ units in 2012), cattle (25,500 in 2012) and poultry.

Figure 6 shows the evolution of the irrigated land and the average water consumption. During the modernization period from the middle of the 1980s, there was a progressive increase in the irrigated area (from 71,000 ha in 1980, to 120,000 ha in 2000 and to almost 126,000 ha in 2010) and an increase in water consumption per ha; this was because of the introduction of crops that consume more water. During the first stage of modernization a clear and consistent trend of increasing water consumption per ha occurred, from approximately $5000 \mathrm{~m}^{3} \mathrm{ha}^{-1}$ in 1980 to $7700 \mathrm{~m}^{3} \mathrm{ha}^{-1}$ in 2000 . Nevertheless, during the 2000s, an average of $6900 \mathrm{~m}^{3} \mathrm{ha}^{-1}$ was consumed, although this was variable depending on the annual availability of water resources. This trend is the consequence of intensification of irrigated crops in the RAA, with the expansion of corn, lucerne, rice and other crops (Playán and Mateos, 2006). In some modernized areas the initiation of sprinkling irrigation has increased the use of summer crops by at least 50\%, and corn has increased in area by a factor of 2.5, increasing water demand (Lecina et al., 2009). Lecina et al. (2011) estimated that water consumption is approximately $48 \%$ higher in the sprinkling irrigation areas. Cazcarro and Sánchez (2009) reported that cropping of winter cereals (wheat and barley; average water consumption 3100-3800 $\mathrm{m}^{3}$ ha) is declining. In contrast, summer cropping is increasing (with some interannual variability), and leading to greater water consumption: corn, $8500 \mathrm{~m}^{3} \mathrm{ha}^{-1}$; lucerne, $10,250 \mathrm{~m}^{3} \mathrm{ha}^{-1}$; and rice, 13,100 $\mathrm{m}^{3} \mathrm{ha}^{-1}$. This increasing water demand to satisfy the water needs of summer crops is creating a severe problem: water resources are limited, and depend on climate variability and the capacity of the reservoirs of the RAA system.

\subsection{Coping with water scarcity: the role of water ponds and small reservoirs}

Figure 6 indicates that the expansion of high water-consuming crops and the increase in the irrigated area has reduced water availability per ha. This is a logical consequence in the context that no large reservoirs have been constructed in the last 35 years. Coming challenges include: (i) an enlargement of the irrigated area towards the south and southeast; and (ii) the modernization of those municipalities in which gravity irrigation currently dominates. Both these challenges represent an increase in water demand in the future. Managers of the RAA and of the Ebro River Administration Office know that enlargement of the irrigated area is impossible, given the restrictive policy on construction of new large reservoirs in the Gállego and Cinca rivers (see Batalla et al., 2014 and Tuset et al., 2015 to analyse the environmental problems derived from large reservoirs). Thus, the period of large public works has passed, and new strategies are needed to ensure the supply of water to the modernized areas. One of these strategies is the construction of small reservoirs within the RAA system. 
Jlassi et al.
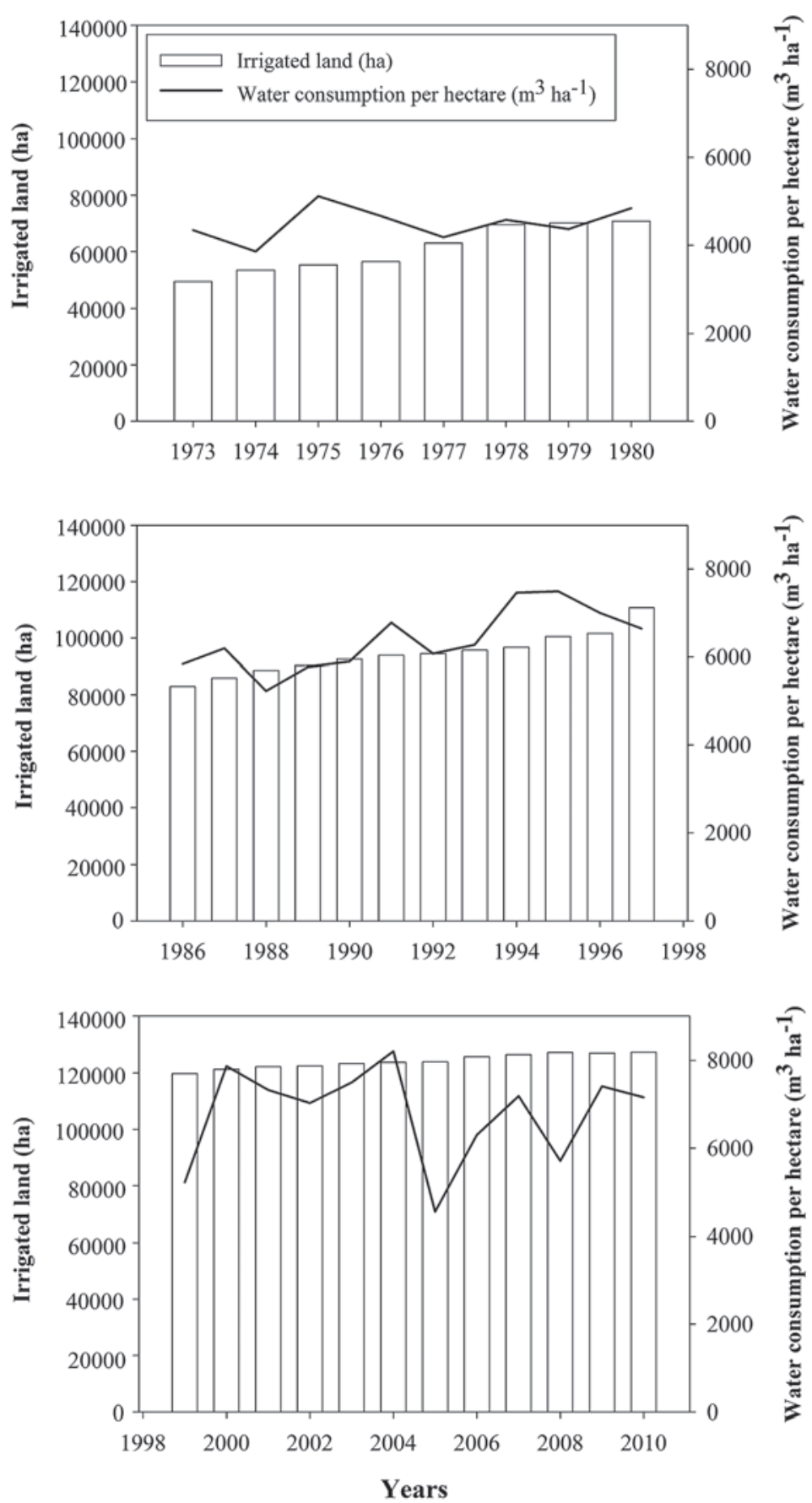

Figure 6. Evolution of irrigated land and water consumption per ha in the RAA. 
Small reservoirs have been constructed in clayey topographic depressions, close to the main canals. In 1983 the Torrollón $\left(1.83 \mathrm{hm}^{3}\right)$ and Valdabra $\left(2.9 \mathrm{hm}^{3}\right)$ reservoirs were constructed, the former storing water from the Flumen Canal and the second from the Cinca Canal. Two new small reservoirs (the Las Fitas reservoir, $9 \mathrm{hm}^{3}$; and the Lasesa reservoir, $6 \mathrm{hm}^{3}$ ) have recently been established close to the Terreu Canal. Nevertheless, the most common strategy has been the construction of water ponds, which have three objectives: (i) to increase the capacity of water storage within the RAA system; (ii) to increase the water pressure to enable sprinkling irrigation; and (iii) to make the procedure of water distribution more flexible. A total of 332 ponds of variable size have been constructed in the study area. Figure 7 shows the predominance of ponds $<5000 \mathrm{~m}^{2}$, and a clear decline in pond number with increasing pond size. The smallest ponds are usually private initiatives, and represent a strategy of individual farmers to solve occasional problems of water availability or to have a store of water for other purposes (e.g. water supply for livestock).

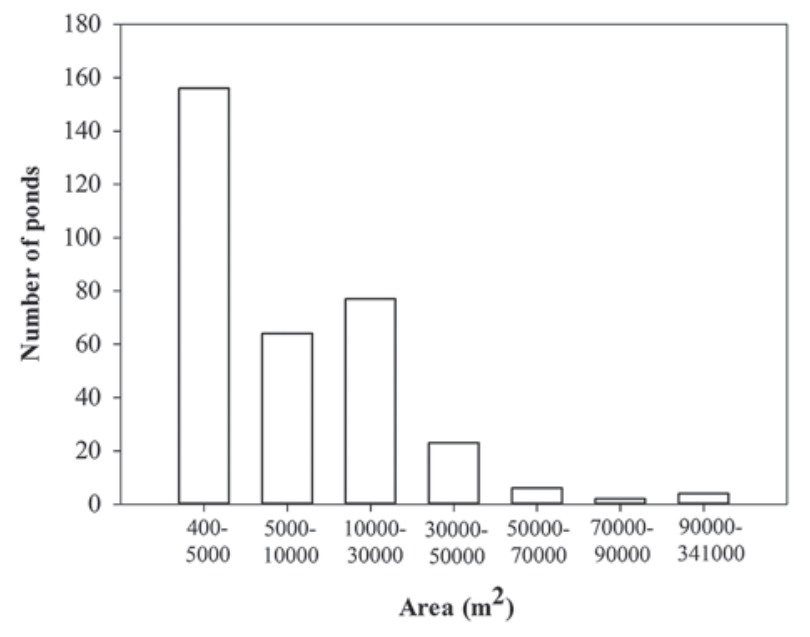

Figure 7. Distribution of the ponds according to pond area.

Figure 8 shows the location of the largest water ponds (exceeding 10,000 $\mathrm{m}^{2}$ ). Many of these appear to be related to the main canals (Flumen, Terreu, Monegros), which directly supply water to the ponds. Detailed information on the characteristics of ponds is available from the RAA Administration Office, but is limited to 89 ponds, that are generally of large size and are publicly owned. All of the larger water ponds were constructed after 1990 (most since 2003; Fig. 9), because of their association with the modernization process. Because of the high cost of construction, which exceeds the capacity of individual farmers and the RAA community, most of the large ponds were built using funds provided by the Spanish Government or the Aragón regional Government, or by the Ebro River Administration Office (which is also dependent on the Spanish Government). Nevertheless, the farmers ultimately pay for the ponds with long-term loans (e.g. 50 years), or through water charges. Figure 10 shows an aerial view of two ponds close to the small Torrollón reservoir. 


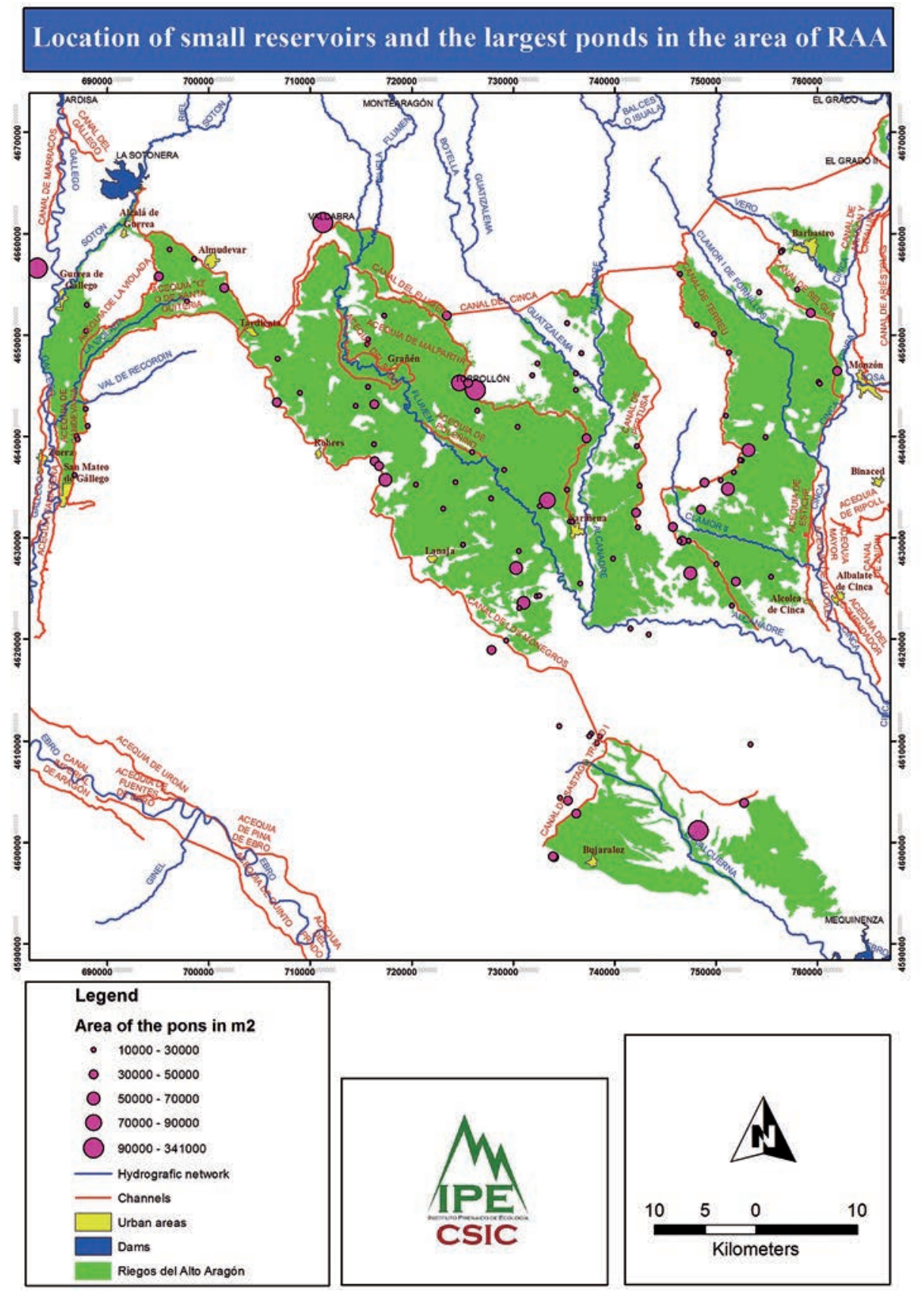

Figure 8. Location of small reservoirs and the largest ponds in the RAA area. 


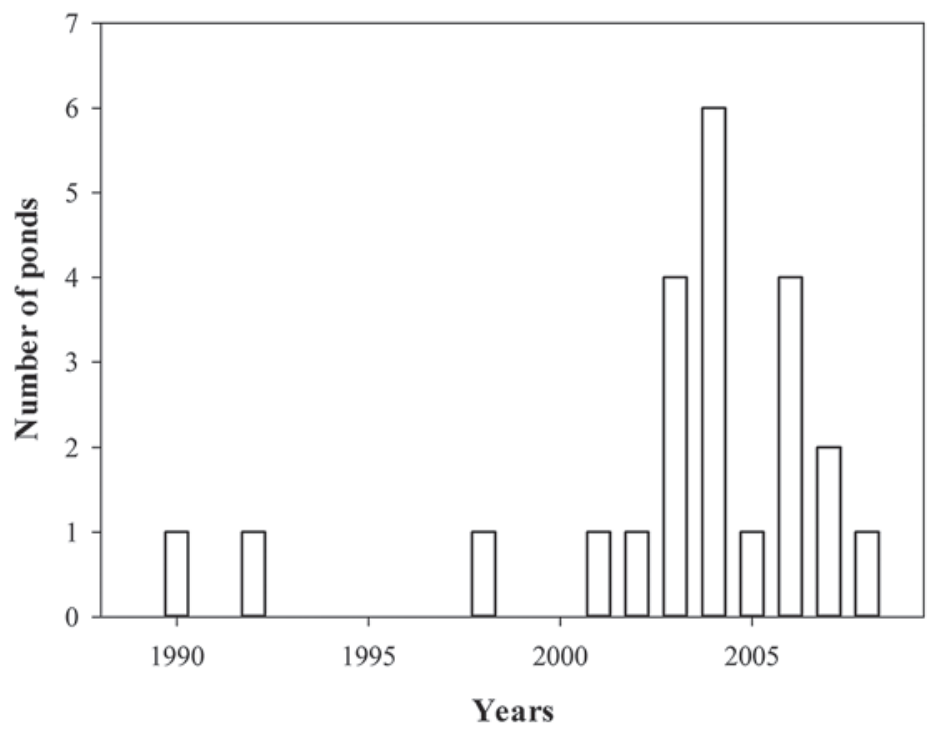

Figure 9. Distribution of the ponds according to the year of construction.

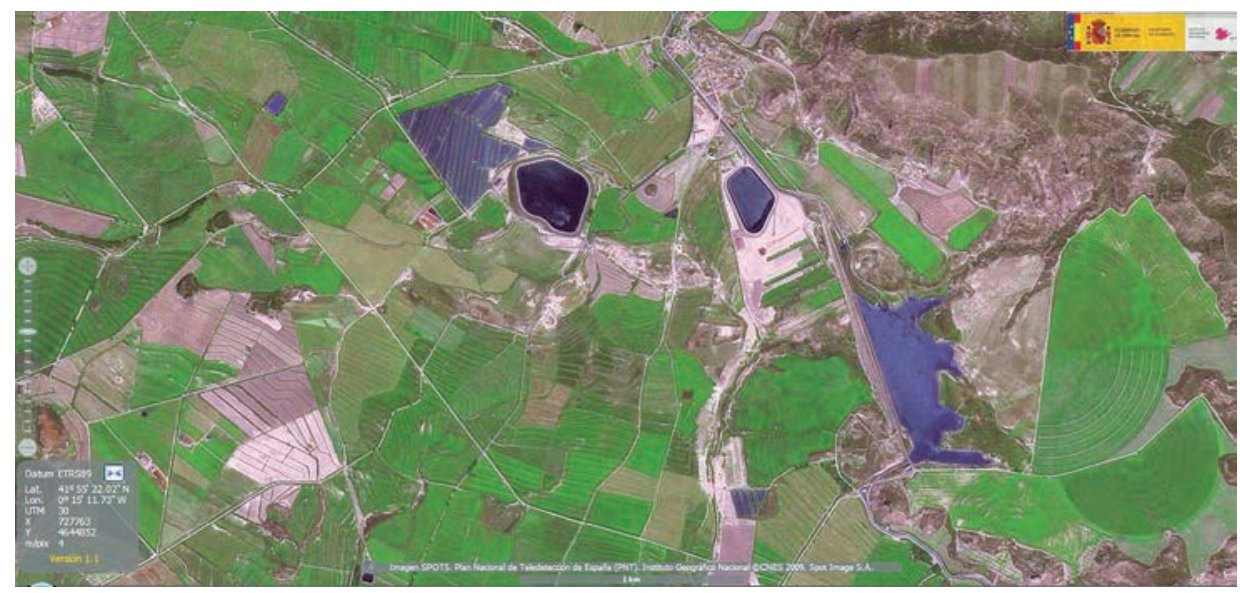

Figure 10. Ponds and the small reservoir of Torrollon, close to the municipality of Marcén. Source: IBERPIX, IGN.

Water ponds are important in the functioning of the RAA, and particularly for the modernization process of the RAA. Small and medium sized private water ponds help to overcome critical periods of water scarcity in some plots. The largest ponds, which are managed by the RAA community or by local farmer communities, are used to solve more general problems, associated with the irrigation process. The main advantages of the public ponds include the following: 
(i) The ponds represent a large water store from which the distribution of water to a community of farmers is centralized. Each pond contributes to increasing the water pressure, which facilitates operation of the sprinkling and drip irrigation, although it involves high energy costs because the water is pumped from the canal to the pond and then distributed to the fields.

(ii) The ponds increase the overall capacity of water storage in the RAA. Most modern ponds exceed $100,000 \mathrm{~m}^{3}$ in capacity and some can store up to $1,000,000 \mathrm{~m}^{3}$ (Fig. 11). If the new small reservoirs are taken into account, the total storage capacity can equate a middle size reservoir (approximately $30 \mathrm{hm}^{3}$ ). It is noteworthy that the water ponds can also provide water for domestic supply to villages, for at least 30 days.

(iii) The volume of water stored in water ponds and small reservoirs increases the self-regulation capacity in the irrigation system. Ponds provide storage capacity to meet the water demands of each irrigation community for at least two days. Thus, irrigation does not depend immediately on water released from the main reservoirs of the Gállego and Cinca rivers, but from the water resources available in the ponds. This ensures water availability in the very short term.

(iv) Ponds contribute to improved water management by reducing water losses and waste, and increasing the flexibility of the irrigation system. For instance, it is relatively common that a farmer requests irrigation and then decides to not irrigate (for example, because of rainfall or wind). In such cases, the water remains stored in the pond. In the past that water would have been delivered to the drainage canal and consequently wasted. With establishment of the ponds, water is used more efficiently at the most appropriate time.

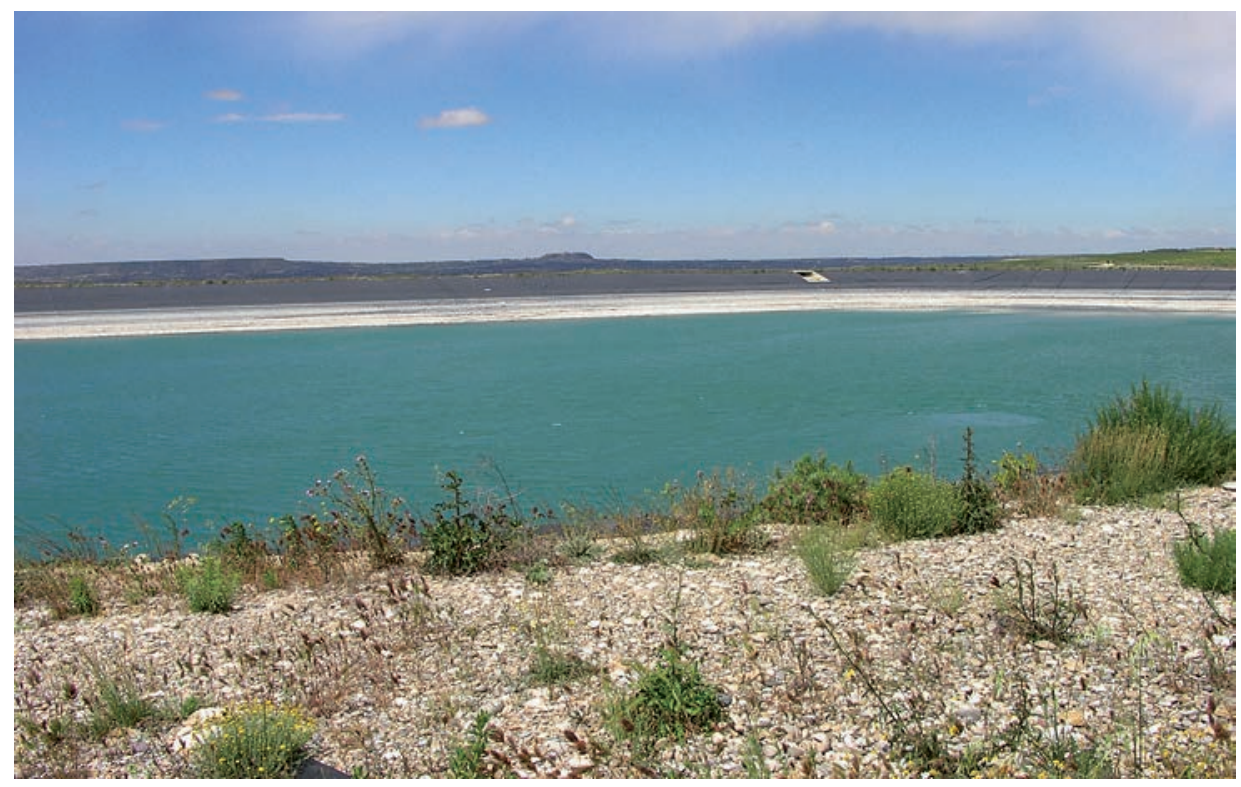

Figure 11. Large pond in the eastern sector of the RAA. 
However, integration of water ponds into the irrigation system of the RAA has created a very difficult problem. Pumping of water from canals to ponds or from ponds to irrigated fields, represents a huge increase in electricity consumption; electricity has become increasingly expensive in recent years and particularly since 2006. This necessitates implementation of new irrigation strategies to control this critical factor. Given that the price of the electricity is lower during the night, many irrigation communities pump and distribute water at night, and farmers must adapt to this new situation (Abad-Piracés, 2010).

Nevertheless, evaporation in the water ponds can represent a relatively important volume of water losses. López-Moreno (2008) estimated the annual evaporation in the Pyrenean reservoirs, recording up to $22 \mathrm{hm}^{3}$ in the Yesa reservoir (Upper Aragón River basin). This value only represents $4.9 \%$ of the total storage capacity of the Yesa reservoir, although it will increase in the near future given the actual trend of annual temperature. Considering that water ponds occupy at least 350 ha in the RAA system, a minimum water loss of $2.6 \mathrm{hm}^{3}$ (about $7.5 \%$ of the total storage capacity) can be estimated.

\section{Discussion and conclusions}

Modernization of irrigated systems is a major objective in many of the Spanish irrigated areas (Morales Gil, 2003) to satisfy the increasing water demand and the necessity of improving agricultural production. This is the case for the Ebro Valley (Castelló, 1989; Frutos et al., 2008), the Duero Valley (Baraja Rodríguez and Molinero Hernando, 2008), the Guadalquivir Valley (Gómez-Limón et al., 2013), and southeast Spain (Gómez Espín et al., 2005; López Fernández and Gómez Espín, 2008; Martínez Medina and Gómez Espín, 2008; Pérez Morales, 2008; Grindlay et al., 2011). This includes the renewal of water pipes, the construction of ponds to increase the water storage capacity (Martínez Medina and Gómez Espín, 2008), plot concentration (Gil Meseguer and Gómez Espín, 1987), and the generalization of new irrigation systems such as sprinkling and drip irrigation. The objectives of modernization have been particularly to improve the efficiency in the use of water and the quality of the return flows from the irrigated areas, to contribute to natural resources (i.e. wet areas) conservation (Playán and Mateos, 2006; Frutos et al., 2008; Lecina et al., 2010), to increase agricultural production, and to improve the livelihood of the rural population (Plusquellec, 2009). This has resulted in a reduction of $12 \%$ of water consumption in the irrigated areas of Spain since mid-1990s (López-Gunn et al., 2012), and the traditional policy of creating new irrigated areas has been substituted to irrigation modernization, introducing more profitable crops and limiting nonpoint pollution (Albiac et al., 2007; Barros et al., 2011).

In the case of the RAA, there are two distinct areas, one modernized and the other not yet modernized. The former area is highly productive, using modern and complex irrigation systems; the latter is poorly efficient and has little capacity to change in the near future. Nevertheless, the modernized irrigated area faces many problems, particularly the high costs of modernization and the energy needed to operate the system. 
The modernization process is very expensive in terms of landscape transformation (i.e. plot concentration and subsequent erosion risk), equipment (cost of pipes and sprinklers) and redemption of the ponds in the long term. Besides, the modernized irrigated areas consume much electric power to pump water at sufficient pressure to enable sprinkling irrigation, making farmers increasingly indebted to banks and public enterprises. A consequence has been the intensification of farming to increase incomes, including the expansion of crops that consume much more water than the winter cereals that are cropped extensively in the non-modernized sector of the RAA (Lecina et al., 2010). This explains the large area cropped with corn, lucerne and rice, and other profitable crops including endives and vegetables. Many farmers produce two crops per year in each field: winter cereals (wheat, barley) from November to May-June, followed by corn from June to October-November. This intensification has been associated with: (i) an increase in water consumption, because of the expansion of high waterconsuming crops in summer and the subsequent increase of evapotranspiration (Playán and Mateos, 2006; Lecina et al., 2010); and (ii) an increase in pig manure consumption to maintain high productivity $\left(6000 \mathrm{~kg} \mathrm{ha}^{-1} \mathrm{yr}^{-1}\right.$ in the case of winter cereals; 12,000 $16,000 \mathrm{~kg} \mathrm{ha}^{-1} \mathrm{yr}^{-1}$ in the case of corn). It is clear that modernization has not represented a saving of water (Playán and Mateos, 2006), but has enabled more efficient water use enabling: (i) production of a greater variety of crops and increased incomes; and (ii) a reduction in water outputs (return flows) via drainage canals (Lecina et al., 2009, 2010), as the use of sprinklers has improved water management and ensured better use of water resources. However, no new immigrants have been attracted, nor the progressive declining population has been avoided (Clar and Silvestre, 2006), due to and extremely high mechanization of labours and the scarce presence of agroindustries.

Nevertheless, two main problems associated with modernization are evident:

(i) Modernization has involved an increase in the complexity in the irrigation system, including the construction of small reservoirs and numerous water ponds, and resulted in higher energy costs in addition to the debts incurred by farmers in the modernization process coinciding with the liberalization of the electricity market in Spain (Rocamora et al., 2013), and making difficult the profitability of modernization projects (Corominas, 2010). This is a major problem that also affects to other irrigated areas in Spain, like the Duero (Baraja Rodríguez and Molinero Hernando, 2008) and the Guadalentín Valley (Martínez Molina and Gómez Espín, 2008). This has led to efforts to increase the productivity of fields at the expense of possible soil contamination and erosion.

(ii) Figure 7 indicates that the RAA system has reached its limits in terms of both the irrigated area and the availability of water per ha, making the system vulnerable to internal and external changes. The supply of water to the fields remained constant throughout the 2000s, following a decade of continuous increase, and the occurrence of dry years (for instance, 2005 and 2012) has necessitated a change in crops (reducing the area of corn and rice) and a reduction in the irrigated area in summer (Jlassi, 2012). It is also noteworthy 
that the availability of water resources has decreased in the Pyrenean rivers (Beguería et al., 2003) as has occurred in many other Mediterranean mountain areas, because of forest and shrub colonization of fields that were abandoned in the second half of the 20th century (García-Ruiz and Lana-Renault, 2011). This trend of decreasing water resources will probably continue in the future, based on the foreseeable landscape evolution of the mid- and sub-alpine mountain belts and the climate models forecasted for the Mediterranean region (LópezMoreno et al., 2008; García-Ruiz et al., 2011), whereas irrigation requirements will probably increase (Savé et al., 2012).

Vicente-Serrano and Cuadrat-Prats (2007) demonstrated the occurrence of a significant increase in the magnitude of drought periods from 1951 to 2000 in the middle Ebro Valley. Vicente-Serrano (2013) identified several regions in Spain showing an increase in the severity of droughts (particularly Southwestern Spain, Catalonia and the Central Ebro basin) (see also Coll et al., 2016; Gouveia et al., 2016). An increase in the duration of dry spells in the Central Ebro Valley was detected by López-Moreno et al. (2010) in winter, spring and summer, and González-Hidalgo et al. (2011) recorded a large decline in the late winter and early spring precipitation (February-March). The severity of droughts because of the occurrence of long periods with anomalous low precipitation is being also enhanced because of the increased potential evapotranspiration in Spain (Vicente-Serrano et al., 2010), and the decrease identified in relative humidity between 1961 and 2011 (Vicente-Serrano et al., 2014). Such trends have been accompanied by an increase in the mean maximum temperature during the last few decades, including also an increase in the frequency and magnitude of warm nights, warm days and tropical nights for the period 1960-2006 (El Kenawy et al., 2011). The consequence in the landscape of the rainfed areas of the Central Ebro basin has been a trend toward decreased vegetation cover, behaving as an early warning of landscape degradation in semi-arid Mediterranean areas (Vicente-Serrano et al., 2012; Gouveia et al., 2016; Vicente-Serrano, 2016). Milano et al. (2013) forecast a temperature increase of $1.5-3^{\circ} \mathrm{C}$ and a precipitation decrease of $15-20 \%$ for the 2050 horizon in the Ebro Valley. Consequently, water resources could decrease by $10-20 \%$, resulting in water shortages. López-Moreno et al. (2011) and García-Garaizábal et al. (2014) also concluded a strong negative impact of climate and land uses evolution on water yield in the Ebro Valley. Changes in snow accumulation and melt regimes result in changes in the seasonal distribution of discharges, causing occasional problems to reservoir management (López-Moreno et al., 2004). According to climate change scenarios, water resources will be severely reduced in Spain, where the Ebro Valley will reduce runoff between 10 and 19\% through the 21st century (Estrela et al., 2012). Similar values have been forecasted for the Euro-Mediterranean region (Santini et al., 2014). This represents increasing difficulties to attend the water demand, and also advises against any future expansion of the irrigated area. Perhaps maximising productivity per unit of water instead of maximising the productivity per unit of land will be a solution for the immediate future (Pereira et al., 2002).

New strategies are urgently needed to reduce the evident fragility of the system, including the construction of new small reservoirs within the area of the RAA to increase the internal water storage capacity, and improvements in water distribution 
in the non-modernized sector. Nevertheless, even though small reservoirs and ponds contribute to improve water management within the RAA system, they increase the water losses by evaporation. Besides, it is interesting to note that part of the evaporated water has been previously pumped from the main canals, with the corresponding costs of energy. This problem will also affect the projected Almudévar reservoir, which will only store pumped water. There are other possibilities, including automation of the water distribution to take account of the crop type and the soil water content, enabling precise supply of the water needs in each field at different times of the year. Important progress has been made in this area, with positive results including on-line information about the water requirements of each crop type. The ADOR informatics program is increasingly used for water distribution in the various irrigation communities of the RAA (Playán et al., 2007). This is a strategy for ensuring the sustainability of the RAA irrigation system under future conditions of increasing temperature, increasing interannual variability of precipitation, and reduction in the availability of water resources associated with declining stream flows (García-Ruiz et al., 2011). The incorporation of Information and Communication Technologies has represented an improvement of the water distribution efficiency, a save of water, and a reduction of the energy costs (Lorite et al., 2007; SotoGarcía et al., 2013).

To sum up, modernization of the RAA system represents new expectations for farmers (mainly an increase in crop productivity and improvements in water management) accompanied by increased costs of energy that are essential for the functioning of the system, and very high costs of land transformation and increased evapotranspiration (Playán and Mateos, 2006). In fact, this means that RAA erroneously designed since the beginning, obligating the farmers to constant and expensive adjustments with the purpose of increasing the productivity and to cope with water scarcity. Consequently, modernization has contributed to demonstrate that this is a highly instable system supported by an increasingly complex organization, higher production costs, and the search of the most adequate crops in relation to water resources availability, manpower, and subsidies from the European Union.

\section{Acknowledgements}

Support for this research was provided by the projects ESPAS (CGL2015-65569-R); INDICA (CGL2011-27753-C02-01 and -02), HIDROCAES (CGL2011-27574-C02-01) and DESEMON (CGL2014-52135-C3-3-R) (MINECO/FEDER); ACQWA (FP7ENV-2007-1-212250), financed by the European Commission; and an agreement between the CSIC and the Spanish Ministry of Environment (RESEL). The research groups on Geomorphology and Global Change and Climate, Water, Global Change and Natural Systems were financed by the Aragón Government and the European Social Fund (ESFFSE). E. Nadal-Romero was the recipient of a "Ramón y Cajal" postdoctoral contract (Spanish Ministry of Economy and Competitiveness).

\section{References}


Abad-Piracés, J. 2010. Problemática de la modernización de regadíos en las comunidades de regantes. XII Congreso Nacional de Comunidades de Regantes de España, Tarragona, 36 pp.

Albiac, J., Playán, E., Martínez, Y. 2007. Instruments for water quantity and quality management in the agriculture of Aragón. Water Resources Development 23, 147-164.

Baraja Rodríguez, E., Molinero Hernando, F. 2008. Nueva dinámica de los paisajes del regadío en el Duero. In J.M. Gómez Espín, R. Martínez Medina (eds.), Los espacios rurales españoles en el nuevo siglo, Universidad de Murcia, Murcia, pp. 111-125.

Barros, R., Isidoro, D., Aragüés, R. 2011. Long-term water balances in La Violada Irrigation District (Spain): II. Analysis of irrigation performance. Agricultural Water Management 98, 1569-1576.

Batalla, R.J., Vericat, D., Tena, A. 2014. The fluvial geomorphology of the lower Ebro (2002-2013): bridging gaps between management and research. Cuadernos de Investigación Geográfica 40 (1), 29-51. Doi: 10.18172/cig.2569.

Beguería, S., López-Moreno, J.I., Lorente, A., Seeger, M., García-Ruiz, J.M. 2003. Assessing the effects of climate oscillations and land-use changes on streamflow in the Central Spanish Pyrenees. Ambio 32, 283-286.

Bouzaida, M.A. 2004. El impacto socioeconómico y físico de las transformaciones en regadío de una zona semiárida: Monegros. Unpublished Master Thesis, IAMZ, Zaragoza.

Bouzaida, M.A., Frutos, L.M. 2006a. La contribución del regadío a la mejora de la renta agraria de Los Monegros. Geographicalia 49, 71-98.

Bouzaida, M.A., Frutos, L.M. 2006b. Las repercusiones de las reformas agrarias del Plan de Riegos del Alto Aragón en la población de la comarca aragonesa de Los Monegros. Investigaciones Geográficas 40, 35-53.

Castelló, A. 1989. Propiedad, uso y explotación de la tierra en la comarca de los Monegros oscenses. Instituto de Estudios Altoaragoneses, Huesca, 308 pp.

Causapé, J., Quílez, D., Araguiés, R. 2006. Irrigation efficiency and quality of irrigation return flows in the Ebro River basin: An overview. Environmental Monitoring and Assessment 117, 451-461.

Causapé, J., Merchán, B., Abrahâo, R., García-Garizábal, I. 2012. Alteración hidrológica del barranco de Lerma (Zaragoza) por la transformación del regadío. Cuadernos de Investigación Geográfica 38 (2), 91-106. Doi: 10.18172/cig.1284.

Cavero, J., Beltrán, A., Araguiés, R. 2003. Nitrate exported in the drainage water of two sprinkler irrigated watersheds. Journal of Environmental Quality 32, 916-926.

Cazcarro, I., Sánchez, J. 2009. Agua virtual azul y agua virtual azul en la economía de Huesca. Boletín de Riegos del Alto Aragón 25, 6-12.

Clar, E., Silvestre, J. 2006. Impactos demográficos del regadío en las comarcas afectadas por Riegos del Alto Aragón. In Riegos del Alto Aragón. Impacto económico y social, Riegos del Alto Aragón, Huesca, pp. 219-235.

Coll, J.R., Aguilar, E., Prohom, M., Sigró, J. 2016. Long-term drought variability and trends in Barcelona (1787-2014). Cuadernos de Investigación Geográfica 42 (1), 29-48. Doi: 10.18172/ cig.2927.

Corominas, J. 2010. Agua y energía en el riego, en la época de la sostenibilidad. Ingeniería del Agua 17 (3), 219-233.

El Kenawy, A., López-Moreno, J.I., Vicente-Serrano, S.M. 2011. Recent trends in daily temperature extremes over northeastern Spain (1960-2006). Natural Hazards and Earth System Science 11, 2583-2603.

Estrela, T., Pérez-Martín, M.A., Vargas, E. 2012. Impacts of climate change on water resources in Spain. Hydrological Sciences Journal 57 (6), 1154-1167. 
Faci, J.M., Bensaci, A., Slatni, A., Playán, E. 2000. A case study for irrigation modernisation I. Characterisation of the district and analysis of water delivery records. Agricultural Water Management 42, 313-334.

Fernández Marco, J.I. 1961. El Canal Imperial de Aragón. Estudio Geográfico. Consejo Superior de Investigaciones Científicas, Zaragoza, 179 pp.

Frutos, L.M. 1993. Los cambios en la agricultura de regadío aragonesa (1950-1990). In A. Gil Olcina, A. Morales Gil (eds.), Medio siglo de cambios agrarios en España, Instituto de Cultura Juan Gil-Albert, Alicante, pp. 771-803.

Frutos, L.M., Castelló, A., Hernández, M.L., Ruiz Budría, E. 2008. La modernización de los regadíos en Aragón. Acciones y perspectivas. In J.M. Gómez Espín, R. Martínez Molina (eds.), Los espacios rurales españoles en el nuevo siglo, Universidad de Murcia, Murcia, pp. 111-125.

García-Garaizábal, I., Causapé, J., Abrahao, R., Merchan, D. 2014. Impact of climate change on Mediterranean irrigation demand: historical dynamics of climate and future projections. Water Resources Management 28 (5), 1449-1462.

García-Ruiz, J.M. 2011. Una revisión de los procesos de sufosión o piping en España. Cuadernos de Investigación Geográfica 37 (1), 7-24.

García-Ruiz, J.M., Lana-Renault, N. 2011. Hydrological and erosive consequences of farmland abandonment in Europe, with special reference to the Mediterranean region - A review. Agriculture, Ecosystems and Environment 140, 317-338.

García-Ruiz, J.M., Lasanta, T., Alberto, F. 1997. Soil erosion by piping in irrigated fields. Geomorphology 20, 269-278.

García-Ruiz, J.M., Lasanta, T., Biarge, F. 2003. Agua, tierra y paisaje. Complejidad y diversidad en el territorio de Riegos del Alto Aragón. Confederación Hidrográfica del Ebro y Comunidad General de Riegos del Alto Aragón, Zaragoza, 164 pp.

García-Ruiz, J.M., Beguería, S., López-Moreno, J.I., Lorente, A., Seeger, M. 2001. Los recursos hídricos superficiales del Pirineo aragonés y su evolución reciente. Geoforma Ediciones, Logroño, $192 \mathrm{pp}$.

García-Ruiz, J.M., López-Moreno, J.I., Vicente-Serrano, S.M., Lasanta, T., Beguería, S. 2011. Earth-Science Reviews 105 (3-4), 121-139.

García-Ruiz, J.M., Beguería, S., Vicente-Serrano, S.M., López-Moreno, J.I., Lana-Renault, N., Lasanta, T. 2010. Innovative technology and institutional options in rainfed and irrigated agriculture in the Tagus basin. In G.D. Gooch, A. Rieu-Clarke, P. Stalnake (eds.), Integrating water resources management, Iwa Publishing, London, pp. 71-80.

Gil Meseguer, E., Gómez Espín, J.M. 1987. Los proyectos de concentración parcelaria en los regadíos del Trasvase Tajo-Segura. Papeles de Geografía 12, 91-101.

Gómez Espín, J.M., Gil Meseguer, E., García Marín, R. 2005. Insuficiencias hídricas y modernización de regadíos en la Cuenca de Mula. Papeles de Geografía 41-42, 101-121.

Gómez-Limón, J.A., Arriaza, M., Villanueva, A.J. 2013. Typifying irrigated areas to support policy design and implementation: the case of the Guadalquivir River basin. Irrigation and Drainage 62, 322-329.

González-Hidalgo, J.C., Brunetti, M., de Luis, M. 2011. A new tool for monthly precipitation analysis in Spain: MOPREDAS database (Monthly precipitation trends December 1945-November 2005). International Journal of Climatology 31, 715-731.

Gouveia, C.M., Páscoa, P., Russo, A., Trigo, R.M. 2016. Land degradation assessment over Iberia during 1982-2012. Cuadernos de Investigación Geográfica 42 (1), 89-112. Doi: 10.18172/ cig. 2945 . 
Grindlay, A.L., Lizárraga, C., Rodríguez, M.I., Molero, E. 2011. Irrigation and territory in the southeast of Spain. Evolution and future perspectives within a new hydrological planning. WIT Transactions on Ecology and the Environment 150, 623-638.

Higueras, A. 1969. La agricultura de regadío en España. In Miscelánea a Canellas, Universidad de Zaragoza, Zaragoza, pp. 585-630.

Ibarra-Benlloch, P., Pinilla-Navarro, V. 1999. Regadío y transformaciones agrarias en Aragón (1880-1990). In R. Garrabau, J.M. Naredo (eds.), El agua en los sistemas agrarios. Una perspectiva histórica, Fundación Argentaria, Madrid, pp. 391-426.

Ibarra, P., de la Riva, J. 2006. El medio físico de la zona de Riegos del Alto Aragón. In L. Germán (coord.), Riegos del Alto Aragón. Impacto económico y social 1953-2003, Comunidad General de Riegos del Alto Aragón, Huesca, pp. 15-53.

Isidoro, D., Grattan, S.R. 2011. Predicting soil salinity in response to different irrigation practices, soil types and rainfall scenarios. Irrigation Science 29, 197-211.

Isidoro, D., Quílez, D., Aragüés, R. 2006. Environmental impact of irrigation in La Violada district (Spain): II. Nitrogen fertilization and nitrate export patterns in drainage water. Journal of Environmental Quality 35, 776-785.

Jlassi, W. 2012. La gestión del agua en Riegos del Alto Aragón: De los grandes embalses a las pequeñas balsas. Unpublished Master Thesis, Instituto Agronómico Mediterráneo de Zaragoza, Zaragoza.

Laliena, C. 2008. Agua y progreso social en Aragón, siglos XII-XVIII. In ¿Agua pasada? Regadíos en el Archivo Histórico Provincial de Zaragoza, Gobierno de Aragón, Zaragoza, pp. 53-84.

Lasanta, T. 2009. Cambios de función en los regadíos de la Cuenca del Ebro: Un análisis del papel de los regadíos a lo largo del tiempo. Boletín de la A.G.E. 50, 81-110.

Lasanta, T., García-Ruiz, J.M., Pérez-Rontomé, C., Sancho-Marcén, C. 2000. Runoff and sediment yield in a semi-arid environment: the effect of land management after farmland abandonment. Catena 38, 265-278.

Lasanta, T., Pérez-Rontomé, M.C., Machín, J., Navas, A., Mosch, W., Maestro, M. 2001. La exportación de solutos en un polígono de regadío de Bardenas (Zaragoza). Cuaternario y Geomorfología 15 (3-4), 51-66.

Lecina, S., Isidoro, D., Playán, E., Aragüés, R. 2009. Efecto de la modernización de regadíos sobre la cantidad y la calidad de las aguas: la Cuenca del Ebro como caso de estudio. Madrid, Instituto Nacional de Investigación y Tecnología Agraria y Alimentaria, pp. 5-90.

Lecina, S., Isidoro, D., Playán, E., Aragüés, R. 2010. Irrigation modernization and water conservation in Spain: The case of Riegos del Alto Aragón. Agricultural Water Management 97, 1663-1675.

Lecina, S., Isidoro, D., Playán, E., Araguiés, R. 2011. Modernización de regadíos: Ventajas y limitaciones. Monográfico Riegos del Alto Aragón, II Jornada Técnica, Comunidad de Riegos del Alto Aragón, Huesca, pp. 5-8.

López Fernández, J.A., Gómez Espín, J.M. 2008. Efectos de la sequía en la modernización de los regadíos de Mula. In J.M. Gómez Espín, R. Martínez Medina (eds.), Los espacios rurales españoles en el nuevo siglo, Universidad de Murcia, Murcia, pp. 145-160.

López-Gunn, E., Zorrilla, P., Prieto, F., Llamas, M.R. 2012. Lost in traslation? Water efficiency in Spanish Agriculture. Agricultural Water Management 108, 83-95.

López-Moreno, J.I. 2005. Recent Variations of snowpack depth in the Central Spanish Pyrenees. Arctic, Antarctic and Alpine Research 37, 253-260.

López-Moreno, J.I. 2008. Estimación de pérdidas de agua por evaporación en embalses del pirineo. Cuadernos de Investigación Geográfica 34, 61-81. 
Jlassi et al.

López-Moreno, J.I., García-Ruiz, J.M. 2004. Influence of snow accumulation and snowmelt on streamflow in the Central Spanish Pyrenees. Hydrological Sciences Journal 49, 787-802.

López-Moreno, J.I., García-Ruiz, J.M., Beniston, M. 2008. Environmental change and water management in the Pyrenees. Facts and future perspectives for Mediterranean mountains. Global and Planetary Change 66, 300-312.

López-Moreno, J.I., Vicente-Serrano, S.M., Beguería, S., El Kenawy, A.M., Angulo, M. 2010. Trends in daily precipitation of the north-eastern Iberian Peninsula, 1955-2006. International Journal of Climatology 30, 1026-1041.

López-Moreno, J.I., Vicente-Serrano, S.M., Morán-Tejeda, E., Zabalza, J., Lorenzo-Lacruz, J., García-Ruiz, J.M. 2011 Impact of climate evolution and land use changes on water yield in the Ebro basin. Hydrology and Earth System Science 15, 311-322.

Lorite, I.J., Mateos, L., Orgaz, F., Fereres, E. 2007. Assessing deficit irrigation strategies at the level of an irrigation district. Agricultural Water Management 91, 51-60.

Martínez Medina, R., Gómez Espín, J.M. 2008. Modernización de regadíos en el valle del Guadalentín. In J.M. Gómez Espín, R. Martínez Medina (eds.), Los espacios rurales españoles en el nuevo siglo, Universidad de Murcia, Murcia, pp. 161-180.

Milano, M., Ruelland, D., Dezetter, A., Fabre, J., Ardoin-Bardin, S., Servat, E. 2013. Assessing the capacity of water resources to meet the current and future water demands over the Ebro catchment (Spain). IAHS Publ. 362, 199-206.

Morales Gil, A. 2003. Eficiencias de los regadíos españoles. Cuadernos de Geografía 73-74, 323 342.

Navas, A., Machín, J. 1997. Assessing erosion risks in the gypsiferous steppe of Litigio (NE Spain). An approach using GIS. Journal of Arid Environments 37, 433-441.

Pedrocchi-Renault, C. 1998. Ecología de los Monegros: La paciencia como estrategia de supervivencia. Instituto de Estudios Altoaragoneses, Huesca.

Pereira, L.S., Oweis, T., Zairi, A. 2002. Irrigation management under water scarcity. Agricultural Water Management 57, 175-206.

Pérez Morales, A. 2008. Rentabilidad socioeconómica de los cultivos con riego localizado en la región de Murcia. In J.M. Gómez Espín, R. Martínez Medina (eds.), Los espacios rurales españoles en el nuevo siglo, Universidad de Murcia, Murcia, pp. 181-198.

Pinilla, V. 2008. El desarrollo de la agricultura de regadío en la Cuenca del Ebro en el siglo XX. In V. Pinilla Navarro (ed.), Gestión y usos del agua en la Cuenca del Ebro en el siglo XX, Prensas Universitarias de Zaragoza, Zaragoza, pp. 309-333.

Playán, E., Mateos, L. 2006. Modernization and optimization of irrigation systems to increase water productivity. Agricultural Water Management 80, 100-116.

Playán, E., Salvador, R., Faci, J.M., Zapata, N., Martínez-Cob, A., Sánchez, I. 2005. Day and night wind drift and evaporation losses in sprinkler solid-sets and moving laterals. Agricultural Water Management 76, 139-159.

Playán, E., Cavero, J., Mantero, I., Salvador, R., Lecina, S., Faci, J.M., Andrés, J., Salvador, V., Cardeña, G., Ramón, S., Lacueva, J.L., Tejero, M., Ferri, J., Martínez-Cob, A. 2007. A database program for enhancing irrigation district management in the Ebro Valley (Spain). Agricultural Water Management 87 (2), 209-216.

Plusquellec, H. 2009. Modernization of large-scale irrigation systems: is it and achieveable objective or a lost cause? Irrigation and Drainage 58, 104-120.

Pueyo, Y. 2013. Aportación de los modelos ecohidrológicos con feedbacks al conocimiento del funcionamiento de los ecosistemas de zonas áridas y semi-áridas. Cuadernos de Investigación Geográfica 39 (2), 243-258.

Puy, A. 2014. Land selection for irrigation in Al-Andalus, Spain (8th century a.d.). Journal of Field Archaeology 39 (1), 84-100. 
Rocamora, C., Voera, J., Abadía, R. 2013. Strategy for efficient energy management to solve energy problems in modernized irrigation: analysis of the Spanish case. Irrigation Science 31, 1139-1158.

Sanjuan, Y. 2013. La Política Agraria Común en el Alto Guadiana: Evolución de recursos hídricos y de cultivos. Cuadernos de Investigación Geográfica 39 (2), 359-389. Doi: 10.18172/ cig.1995.

Santini, M., Collalti, A., Valentini, R. 2014. Climate change impacts on vegetation and water cycle in the Euro-Mediterranean region, studied by a likelihood approach. Regional Environmental Change 14 (4), 1405-1418.

Savé, R., de Herralde, F., Aranda, X., Pla, E., Pascual, D., Funes, I., Biel, C. 2012. Potential changes in irrigation requirements and phenology of maize, apple trees and alfalfa under global change conditions in Fluvià watershed during XXIst century: Results from a modelling approximation to watershed-level water balance. Agricultural Water Management 114, 7887.

Soto-García, M., Del-Amor-Saavedra, P., Martín-Gorriz, B., Martínez-Álvarez, V. 2013. The role of information and communication technologies in the modernization of water user associations' management. Computers and Electronics in Agriculture 98, 121-130.

Strosser, P., Pau Vall, M., Plötscher, E. 1999. Water and agriculture: contribution to an analysis of a critical but difficult relationship. EC/IPTS, Towards a sustainable/Strategie management of water resources: evaluation of present policies and orientations for the future in the Mediterranean Sea. The European Commission. Available at: http://ec.europa.eu/ agriculture/envir/report/en/eau_en/report.htm

Tedeschi, A., Beltrán, A., Aragüés, R. 2001. Irrigation management and hydrosalinity balance in a semi-arid area of the middle Ebro river basin (Spain). Agricultural Water Management 49, 31-50.

Tuset, J., Vericat, D., Batalla, R.J. 2015. Evolución morfo-sedimentaria del tramo medio del río Segre. Cuadernos de Investigación Geográfica 41 (1), 23-62. Doi: 1018172/cig.2707.

Vicente-Serrano, S.M. 2013. Spatial and temporal evolution of precipitation droughts in Spain in the last century. In C. García-Legaz, F. Valero (eds.), Adverse weather in Spain, Madrid, WCRP Spanish Committee, pp. 283-296.

Vicente-Serrano, S.M. 2016. Foreword: Drought complexity and assessment under climate change conditions. Cuadernos de Investigación Geográfica 42 (1), 7-11. Doi: 10.18172/cig.2961.

Vicente-Serrano, S.M., Cuadrat-Prats, J.M. 2007. Trends in drought intensity and variability in the middle Ebro valley (NE Spain) during the second half of the twentieth century. Theoretical and Applied Climatology 88, 247-258.

Vicente-Serrano, S.M., Beguería, S., López-Moreno, S. 2010. A multi-scalar drought index sensitive to global warming: The Standardized Precipitation Evapotranspiration IndexSPEI. Journal of Climate 23, 1696-1718.

Vicente-Serrano, S.M., Zouber, A., Lasanta, T., Pueyo, Y. 2012. Dryness in accelerating degradation of vulnerable shrublands in semiarid Mediterranean environments. Ecological Monographs 82 (4), 407-428.

Vicente-Serrano, S.M., Azorín-Molina, C., Sánchez-Lorenzo, A., Morán-Tejeda, E., LorenzoLacruz, J., Revuelto, J., López-Moreno, J.I., Espejo, F. 2014. Temporal evolution of surface humidity in Spain: recent trends and possible physical mechanisms. Climate Dynamics 42 (9), 2655-2674.

Wainwright, J., Thornes, J.B. 2004. Environmental issues in the Mediterranean. Processes and perspectives from the past and present. London, Routledge. 